\title{
ECONOMIC ANALYSIS OF SWAMP RICE PRODUCTION IN EBONYI SOUTHERN AGRICULTURAL ZONE OF EBONYI STATE, NIGERIA
}

\author{
NWAOBIALA .C.U \\ Department of Agricultural Extension and Management \\ Federal College of Agriculture, Ishiagu, Ebonyi State \\ Email: cnwaobiala@yahoo.in 08058924954
}

\begin{abstract}
The aim of the paper is to analyze the determinants and profitability of the output of swamp rice farmers in Ebonyi southern Agricultural zone of Ebonyi State. Primary data were obtained through the use of structured questionnaires. A total of eighty (80) swamp rice farmers were randomly selected from the different blocks and circles of the Zone. The multiple regression analysis (Cobb-Douglas) showed that education had positive effects on the output of swamp rice at 1\% level of probability. Also, household size, farm size and farming experience were statistically significant at 5\% level of probability. The equation explained $71.10 \%$ of the variation in the output of swamp rice production in the study area. The results also indicate that the net profit of swamp rice cultivation per hectare was $\$ 126$, 590.00. Farmers should be encouraged to engage in swamp rice cultivation by providing access to funds. Formation of cooperatives is very essential to overcome financial constraints and ban on rice importation should be enacted to encourage local rice production.
\end{abstract}

Key words: Analysis, swamp rice, Ebonyi south Agricultural zone.

\section{INTRODUCTION}

Rice is the most important cereal in the world after wheat and more than half of the human race needs rice as a source of calories (wakatsuki et al, 2004). It is the leading cereal crop of the south East Asia which constitutes a thick population region of the world (Mani et $a l, 2007)$. Africa accounts for only about $2 \%$ of worlds output of rice. Rice is produced in the middle belt, south East and some far Northern states ( Audu, 2008). The importance of rice in Nigeria is no longer the question but rather, how can we meet the growing demand, reduce import and be self sufficient. The green revolution in the 1960's laid the foundation for rapidly growing economics of Asia today. (Hirose and Wakatsuki 2000). Unfortunately, African is yet to attain its green revolution.

Rice production in Nigeria between 2001 and 2003 was estimated at 2.03 million mega grams, while consumption was 3.96 million mega grams. The balance of 1.90 million mega grams was obtained by importation (FAO, 2004). Total consumption stands at $29 \mathrm{~kg}$ and has contributed to income and growth in Nigeria rice sector (USAD, 2008).

Nigeria is the largest producer of rice in West Africa producing over $40 \%$ of the regions total production (Singh et al, 1997 and FAOSTAT, 2007). In the last 30 years, production has increased 6 folds with Nigeria producing 3.3 and 3.6 million tons of paddy rice in 2000 and 2005 respectively (FAOSTAT, 2004 and 2007).

Nigeria is equally the largest importer of rice and its importation figure stood at 11.61 million metric tons since 2000, which is one third of the sub regions total. It has a land area potential for rice estimated at 5 million hectares of which $65 \%$ are low lands. In 1999 area harvested from rice was 2.2 million ha consumption per capita jumped from $2.9 \mathrm{~kg}$ in the period 1970-74 to $24.1 \mathrm{~kg}$ between 1995-1999 (Hirose and Wakatsuki, 2002). Rice has emerged as one of the fastest growing agricultural sub-sector and has moved from ceremonial to a staple food in many Nigerian homes within the last two decades (Ume et al, 2007). Majority of rice producers in Nigeria are small holders with average size of less than two 
hectares and can be found growing in mixtures on farms. Out of 4.6 million hectares available for rice production only 17 million hectares are put to rice cultivation. Despite that its production is labour intensive and labour represents the major production costs. (Nwachukwu et al, 2008). Current production stands at 2.8 million tons with a deficit of 1.6 million tons excluding the quantities smuggled through porous borders (Erenstein, 2003; Mohapatra, 2007: USAID, 2008). Massive importation of food especially rice which have hither to been a recurring policy initiative in recent years is an indication of poor state of the nations agricultural and technological development, occasioned by poor productive propensity of the farmers. Increase in agricultural import is a disincentive to local farmers to produce and may cause a reduction in farming population which can subsequently lead to a reduction in agricultural output. It is against this background, there is need to examine the economic analysis of swamp rice production in Ebonyi State Agricultural Zone of Ebonyi State. Therefore, the specific objectives of the paper are to:

1. describe the socio-economic characteristics of swamp rice farmers.

2. determine the effect of socio-economic variables of swamp rice farmers on their output levels

3. determine the cost and returns of swamp rice production.

In order to achieve some specific objectives, the following hypothesis were tested.

$\mathrm{H}_{1}$ : Socio-economic characteristics of swamp rice farmers do not have significant effect on the output of rice

$\mathrm{H}_{2}$ : Rice production is not profitable

\section{METHODOLOGY}

The research was conducted in Ebonyi south Agricultural Zone of Ebonyi State. A multistage random sampling technique was used in the selection of agricultural blocks, circles and swamp rice farmers. First four (4) blocks were randomly selected from the zone namely: Afikpo North, Afikpo South, Ohazara and Onicha. Also four (4) circles were randomly selected from each of the selected blocks this gave a total of sixteen (16) blocks. Finally five (5) swamp rice farmers were randomly selected from the circles and this gave a sample size of eighty (80) swamp rice farmers.

The various analysis carried out include the use of frequency counts, multiple regression analysis and Gross margin analysis. Objective I was realized with descriptive statistics such as mean and frequency distribution. Objective 2 was achieved with multiple repression precisely Cobb. Douglas model, while objective 3 was realized with Gross margin analysis.

A. Model specification for Cobb- Douglas function followed that of Nwaobiala and Ezeh (2008).

\section{Cobb- Douglas Function}

$\mathrm{LNY}=\mathrm{b}_{0}+\mathrm{X}_{1}+\mathrm{b}_{2} \mathrm{X}_{2}+\mathrm{b}_{3} \mathrm{X}_{3}+\mathrm{b}_{4} \mathrm{X}_{4}+\mathrm{b}_{5} \mathrm{X}_{5}+\mathrm{b}_{6} \mathrm{X}_{6}+\mathrm{b}_{7} \mathrm{X}_{7}+\mathrm{ei}$

Where

$\mathrm{Y}=$ Output of swamp rice ( tones/ha)

$\mathrm{X}_{1}=$ Gender (Dummy $1=$ man, $0-$ woman $)$

$\mathrm{X}_{2}=$ Age $($ years $)$

$\mathrm{X}_{3}=$ Education

$\mathrm{X}_{4}=$ Household size

$\mathrm{X}_{5}=$ Farm size (ha)

$\mathrm{X}_{6}=$ Labour

$\mathrm{X}_{7}=$ Farming Experience

ei $=$ Error term 
B. Model specification of Gross margin is stated thus in accordance with Ezeh, Nwaobiala and

Ekedo (2009)

$\mathrm{GM}=\Sigma \mathrm{p}_{\mathrm{i}} \mathrm{Q}_{\mathrm{i}}-\Sigma \mathrm{p}_{\mathrm{i}} \mathrm{x} \mathrm{j}$

Where Pi = Unit price of output (

$\mathrm{Q}_{\mathrm{i}}=$ Quantity of output $(\mathrm{kg})$

$\mathrm{P}_{\mathrm{i}}=$ unit price of input ( $)$

$\mathrm{X}_{\mathrm{j}}=$ Quantity of input $(\mathrm{kg})$

\section{RESULTS AND DISCUSSION}

The socio-economic characteristics of respondents are shown in table 1. Majority $(34.0 \%)$ of the farmers had primary education, while $26.25 \%$ acquired secondary education and $16.25 \%$ had tertiary education. Education enhances the adoption of improved innovation by farmers. Majority (55.0\%) of the respondents had household size of 1-5 while $45 \%$ had 610 household size. Large household size has shown to provide cheap and available labour for farming activities in the rural areas (Nwaobiala et al, 2009). Majority $(50.0 \%)$ of the farmers had farm size ranging from 1-3 hectares, $47.5 \%$ of them had 4-6 hectares and 2.5\% had 7-10 farm size. The table also indicates that majority (60\%) of the respondents had 21-30 years farming experience, while $8.75 \%$ of them had 31-40 years of experience. Farming experience enhances more efficient use of scarce resource by small holders in Nigeria (Ekedo et al, 2008).

Table 1: Socio-Economic Characteristics of Swamp Rice Farmers In Ebonyi South Agricultural Zone Of Ebonyi State (N=80)

\begin{tabular}{lll} 
Variables & Frequency & Percentage \\
\hline Education & 18 & \\
No formal education & 28 & 22.50 \\
Primary education & 21 & 34.00 \\
Secondary education & 13 & 26.25 \\
Tertiary education & & 16.25 \\
Household size & 44 & \\
$1-5$ & 36 & 55 \\
$6-10$ & 0 & 45 \\
$11-15$ & & 0 \\
Farm size & 40 & \\
$1-3$ & 38 & 50 \\
$4-6$ & 2 & 47.5 \\
$7-10$ & & 2.5 \\
Farming Experience & 13 & 16.25 \\
$1-10$ & 12 & 15.00 \\
$11-20$ & 48 & 60.00 \\
$21-30$ & 7 & 8.75 \\
$31-40$ & &
\end{tabular}

Source: Field Survey, 2009. 
Journal of Agriculture and Social Research (JASR) VOL. 10, No. 2, 2010

Table 2: Estimates of Socio-Economic Determinant of Swamp rice Farmers Production in Ebonyi south Agricultural Zone Ebonyi State, 2009

\begin{tabular}{lll}
\hline Variables & $\begin{array}{l}\text { Cobb-Douglas } \\
\text { Coefficient }\end{array}$ & T-Values \\
\hline Constant & $8.996^{* * *}$ & 4.369 \\
Gender & 0.018 & 0.47 \\
Age & 0.257 & 0.540 \\
Education & $0.805^{* * *}$ & 3.474 \\
Household size & $0.493^{* *}$ & 2.150 \\
Farm size & $0.549^{* *}$ & 1.994 \\
Labour & 0.042 & 0.197 \\
Farming Experience & $0.417^{* *}$ & 2.015 \\
R $^{\mathbf{2}}$ & 0.711 & \\
F-Ratio & $4.920^{* * *}$ & \\
\hline
\end{tabular}

Source Computed From Field Survey, 2009

$* * * * *$ Significant at $1 \%$ and $5 \%$ level of significance

Table 3: Gross Margin Analysis of the Profitability of Per Hectare Swamp Rice in Ebonyi South Agricultural Zone of Eonyi State, 2009.

\begin{tabular}{|c|c|c|c|c|}
\hline \multicolumn{2}{|c|}{$\begin{array}{l}\text { Items } \\
\text { N'000 }^{\prime}\end{array}$} & Quantity (kg) & Unit price $(\mathbf{k g})$ & Total \\
\hline \multicolumn{5}{|c|}{ Revenue consideration } \\
\hline 1. & Sales of Rice & 1400.0 & 140 & 196.00 \\
\hline 2. & Quantity consumed & 250.0 & & 35.00 \\
\hline 3. & Quantity Stoned & 500.0 & & 70.00 \\
\hline 4. & Quantity given as gift & 40.2 & & 5.63 \\
\hline \multicolumn{2}{|c|}{ Total Revenue } & 2190.2 & & 306.63 \\
\hline \multicolumn{2}{|c|}{ B Variable costs } & Man days & Qty/kg & Price/wage rate \\
\hline 1. & Land clearing & 20 & 600 & 12.00 \\
\hline 2. & Tilling & 25 & 600 & 15.00 \\
\hline 3. & Seeds & 30 & 150 & 4.50 \\
\hline 4. & Planting (Pre-nursery) & 14 & 400 & 5.00 \\
\hline 5 & Field Planting & 20 & 500 & 12.00 \\
\hline 6. & Weeding & 20 & 600 & 12.00 \\
\hline 7. & \multicolumn{4}{|l|}{ Agro chemicals } \\
\hline a. & Fertilizer (8) & & 4000 & 32.00 \\
\hline b. & Herbicides (4) & & 2800 & 11.20 \\
\hline c. & Pesticides (2) & & 1800 & 3.60 \\
\hline 8. & Bird scaring & 12 & 400 & 4.80 \\
\hline 9. & Harvesting & 18 & 400 & 7.20 \\
\hline \multirow[t]{3}{*}{10.} & Processing Bagging anc & & & \\
\hline & Transportation & & & 12.500 \\
\hline & Total variable costs & & & 131.80 \\
\hline
\end{tabular}

Gross margin = A-B

\$306.63 -131.80 = 174.83 


\section{Fixed costs}

1. Permanent labour

2. Interest payment on loan

3. Rent on land

4. Loan Repayment

5. Depreciation costs on tools and equipment

Total fixed costs

Net Profit = GM - TFC

$\$ 174.83 \approx 48.24=\$ 126.59$

\section{Source: Field Survey Data, 2009}

Table 2. Shows the socio-economic factors which formed the independent variables. Cobb- Douglas function was chosen as a lead equation based on the number of significant variables which conform to prior expectation and highest value of coefficient of determination at $0.711 \%$. The table indicates that education had a direct relationship with output of swamp rice farmers and was significant at $1 \%$ probability level. This implies that it is a major factor influencing swamp rice production in the study area. This is in conformity with a prior expectation that as farmers get educated they will be willing to accept and adopt agricultural technologies (Onumadu et al, 2008). Household size had positive relationship with output of swamp rice farmers and was significant at $5 \%$ level. Increase in household size would result to readily availability of cheap labour. Therefore household size is a determinant of output of swamp rice production.

Farm size had positive relationship with output of swamp rice farmers and was significant at $5 \%$ level. This indicates that farm size is a determinant of value of output.

Farming experience also had positive relationship with output of swamp rice and is significant at $5 \%$ level of probability. This implies that farmers with greater farming experience had increased output (Ekedo, 2008). The combined effects of all variables (Gender, age, education, household size, labour, farm size and farming experience) explained $(71.10 \%)$ of the total variation in the output of swamp rice farmers at $1.0 \%$ level of probability. This means that the null hypothesis of non significant effect of the socioeconomic variables of farmers on their output levels was rejected.

Table 3 shows the gross margin analysis of swamp rice farmers in the study area. This posted a total revenue of three hundred and six thousand, six hundred and thirty naira ( $\$ 306,630.00$ ). The average annual or seasonal cost incurred in rice production in Ebonyi south agricultural zone was one hundred and thirty one thousand, eight hundred naira ( 131,800.00). The gross margin was one hundred and seventy four thousand, eight hundred and thirty naira $(\$ 174,830.00)$. The total fixed cost per hectare is forty eight thousand, two hundred and forty naira ( $\$ 8,240.00)$. Thus, each farmer is left with average net profit of one hundred and twenty six thousand five hundred and ninety naira only ( $\$ 126,590.00)$ from a hectare of swamp rice.

\section{CONCLUSION AND RECOMMENDATIONS}

Results had shown that the combined effects of the socio-economic variables have made positive and significant contribution to the output of swamp rice production. Swamp rice production is a profitable enterprise in Ebonyi South Agricultural zone of Ebonyi State, it was recommended that:

1. Government should ensure that farm inputs such as improved rice seeds, fertilizers tractors and agrochemicals are subsidized.

2. Farmers should be encouraged to form cooperatives. 


\section{Journal of Agriculture and Social Research (JASR) VOL. 10, No. 2, 2010}

3. Access road should be provided by government and through community effort in the rural areas thereby facilitating produce evacuation.

4. Blanket ban on rice production should be imposed and sustained to encourage local production.

5. The land use Act of 1990 be reviewed to eliminate difficulties associated with land acquisition for agricultural purposes, this will facilitate agricultural expansion and grow

\section{REFERENCES}

Audu, S.I (2008). Analysis of Cost and Return of Rice Production in Ankpa Local Government Area of Kogi State, Nigeria. Proceedings of the $42^{\text {nd }}$ Annual Conference of ASN held at EBSU, Abakaliki October 19-23 ${ }^{\text {rd }} \mathrm{Pp} 768$.

Enensitein, O. (2003). Rice Production in Nigeria. A Several Report Abidjan WARDA, BOUAKE, Cote d'Ivore.

Ekedo, T.O, Ezeh, C.I and Nwaobiala, C.U (2008). Socio-Economic Determinants of Home Gardeners in Ishiagu, Ivo LGA of Ebonyi State. Nigeria Journal or Rural Sociological (NJRS) Vol. 8(2) December Pp 69-70

Eze, C.I, Nwaobiala, C.U and Ekedo, T.O (2009). Analysis of Cost and Returns of Home Gardening in Ishiagu Ivo LGA of Ebonyi State Nigeria. Journal of Agriculture and Social Research (JASR) Vol. 9 (1) Pp 88-90

FAOSTAT (2004). Food and Agricultural Organization Statistics Division. http://faostatfao.org.

FAOSTAT (2007). Food and Agricultural Organization Division. http://faostat.fao.org/site/336/default.as. ps

Food and Agricultural Organization (2004). Regional Conference for Asia and the Pacific Beijing China, 17-21 May.

Hirose, S. and Wakatsuki, T. (2002). Restoration of Inland Valley Ecosystem in West African Savannah, Norim Tokei, Kyoka, Tokyo Pp60

Mahn, H, Abubakar I.U Ado, S.G, Falaka, A.M Dadari, S.A and Babaji, B.A (2007). "Performance of Rice Varieties as Influenced by Nitrogen and Supplementary Irrigation Kaduna". In Olu Fajo, O.O Omokore, D.F Akpa, G.N and Sanni S.A (eds). Proceedings of the $41^{\text {st }}$ Annual Conference of Agricultural; Society of Nigeria held at I.A.R Samaru, ABU Zaria 22-26 ${ }^{\text {th }}$ October Pp 399.

Mohapatara, S. (2007). Economics to Draw Urgent Attention to Africa Knowing Rice Crisis www. Warda. Org/newsprint. Rice Crisis Africa Centre. Accessed 29/12/2007

Nwachukwu, T.N Agwu, N.M and Eze, C.I (2008) Comparative Study of Consumer Purchase Altitude of Local and Foreign Rice in Abia State. Proceedings of the $42^{\text {nd }}$ Annual conference of Agricultural Society of Nigeria (ASN) held at EBSU Abakaliki, October $19-23^{\text {rd }} \mathrm{Pp} 764-767$

Nwaobiala, C.U, Akele, S.E, Onumadu, F.N and Okoronkwo M.O (2009). Influence of Socio-Economic Factors on Crop Farmers Production in Ogba/Egbema/Ndoni LGA of Rivers State, Nigeria. Global Approaches to Extension Practice (GAEP) Vol. 5 (1) Pp 63-68

Nwaobiala, C.U. and Ezeh, C.I (2008). Effects of Private sector Extension Service on Crop Farmers Production in Ogba/Egbema/Ndoni LAG of Rivers State, Nigeria. Journal of Food fibre Production. Faculty of Agriculture, ABSU, Vol. 1 (1) Pp 50-56

Onumadu, F.N, Nwosu, I.E and Nwaobiala, C.U (2008) Appraisal of Social Benefits of Adoption of Agro Forestry Practices Small- Scale. Farmers in Ratsina State Nigeria. Journal of Food and Fibre Production.Faculty of Agriculture, ABSU vol. 1(1) Pp 7278. 
Singh, B.N (1997). Breeding Objective for Low Rice Improvement in Africa A Paper Presented at International Training Course on Lowland Rice Production and Management IITA ,Ibadan, $16^{\text {th }}$ April- May, Pp 1-16

Ume, J .C Aigawa, S.A Oyebanyi, O.O and Adesola, O.A (2007). Agricultural Policy Instability in Nigeria. The Rice Farmers Ever Adjusting Production, Process National Workshop on Rice Production held in Abuja

USAID, (2008) Improved Package for Rice Production USAID MARKETS. Maximizing Agricultural Reserves and Key Enterprise in Targeted States, Abuja.

Wakatsuki, T, Buri, M.M and Fashola, O.O (2004). Rice Green Revolution and Restoration of Degraded Inland Water shed in West Africa. Through Participatory and SelfSupport Development. In a Book on Participatory Strategy for soil and Water Conservation ERE CON. Institute of Environment Rehabilitation and conservation pp 241-246. 